\title{
Preparation and Flame Retardant Properties of Calcium-Aluminium Hydrotalcite with Root Cutting Silicate Layers as Bamboo Flame Retardants
}

\author{
Ailian Hu $\mathbb{D}^{\circ}$, Chungui Du*(D), Yating Hua, Yingying Shan, Chunlin Liu, Shiqin Chen, Qi Li and Hongwei Yu* \\ College of Chemistry and Materials Engineering, Zhejiang A \& F University, Hangzhou 311300, China; \\ hal15857832323@163.com (A.H.); artyhuaht1@163.com (Y.H.); syy15968566686@163.com (Y.S.); \\ eustaceweaver7187@gmail.com (C.L.); 18768107239@163.com (S.C.); LQ950011@163.com (Q.L.) \\ * Correspondence: chunguidu@163.com (C.D.); yhw416@sina.com (H.Y.)
}

Citation: Hu, A.; Du, C.; Hua, Y.; Shan, Y.; Liu, C.; Chen, S.; Li, Q.; Yu, H. Preparation and Flame Retardant Properties of Calcium-Aluminium Hydrotalcite with Root Cutting Silicate Layers as Bamboo Flame Retardants. Materials 2021, 14, 7319. https://doi.org/10.3390/ma14237319

Academic Editor: Cédric Delattre

Received: 17 October 2021

Accepted: 26 November 2021

Published: 29 November 2021

Publisher's Note: MDPI stays neutral with regard to jurisdictional claims in published maps and institutional affiliations.

Copyright: (C) 2021 by the authors. Licensee MDPI, Basel, Switzerland. This article is an open access article distributed under the terms and conditions of the Creative Commons Attribution (CC BY) license (https:// creativecommons.org/licenses/by/ $4.0 /)$.
Abstract: Bamboo has been widely used in architecture, decoration and other fields because of its advantages of short growth period, high strength and degradability. However, bamboo, as a combustible material like wood, are easy to burn and cause building fires. However, the existing bamboo water-based flame retardants have some shortcomings, such as strong hygroscopicity and easy loss, which limits the application of bamboo products. In order to improve the flame retardant performance of bamboo, $\mathrm{CaAl}-\mathrm{SiO}_{2}$ layered double hydroxide (LDH) as bamboo flame retardant was synthesised by coprecipitation method. The influence of preparation technology on $\mathrm{CaAl}-\mathrm{SiO}_{3}-\mathrm{LDH}$ structures and properties as well as the flame retardant and smoke suppression characteristics of flame retardant-treated bamboo was discussed. The results revealed that the crystallisation temperature, crystallisation time and crystallisation concentration of $\mathrm{CaAl}-\mathrm{SiO}_{3}-\mathrm{LDHs}$ considerably affected its structure and properties. The optimum technological parameters for preparing $\mathrm{CaAl}-\mathrm{SiO}_{3}-\mathrm{LDHs}_{\text {by }}$ using the coprecipitation method are as follows: crystallisation temperature of $100{ }^{\circ} \mathrm{C}$, crystallisation time of $9 \mathrm{~h}$ and $\mathrm{Ca}^{2+}$ solution molar concentration of $0.33 \mathrm{~mol} / \mathrm{L}$. Compared with nonflame-retardant wood, $\mathrm{CaAl}-\mathrm{SiO}_{3}-\mathrm{LDH}$ flame retardant treatment delayed the peak time of the heat release rate by $20 \mathrm{~s}$ and the ignition time by $77.78 \%$ and increased the carbon residue rate by $9.54 \%$. This study can provide reference for the research of new flame retardant for bamboo products.

Keywords: layered double hydroxides (LDHs); root cutting silicate layer; coprecipitation method; preparation; representation; flame retardant; smoke suppression

\section{Introduction}

China is a major exporter of bamboo products, and more than $60 \%$ of popular bamboo flooring, bamboo furniture, planted bamboo and recombinant bamboo exported to Europe and America originates from China. The quality and processing technology of Chinese bamboo products are the global standard [1]. However, bamboo, as wood, is a combustible material, and bamboo products burn easily and cause fires, which can result in heavy casualties and property loss [2], which considerably limits the application of bamboo products in architecture and decoration [3]. Therefore, increasing the fire resistance of bamboo through flame-retardant treatment is critical.

Currently, phosphorus-nitrogen and nitrogen-phosphorus-boron composites are typically used as bamboo flame retardants. Most of these retardants are inexpensive, waterbased inorganic flame retardants that exhibit flame retardant effects, limited pollution and low price [4]. However, water-based inorganic flame retardants present disadvantages, such as strong hygroscopicity, easy loss and easy precipitation from the treated material surface (frost resistance) [5]. Although there are many new flame retardants [6], like, Gurjot S. Dhaliwal et al. [7] prepared soy-based PU foams by add nanoclay (cloisite na+). Dan Zhang et al. [8] designed and obtained a new environmentally friendly organic hybrid 
flame retardant $\mathrm{CA}\left(\mathrm{H}_{2} \mathrm{PO}_{4}\right)_{2} @ \mathrm{HCCP}$ by surface treatment technology to overcome the shortcomings of water-based inorganic flame retardants, layered double hydroxides (LDHs) were developed. LDHs are typical anionic materials with metal hydroxide as the main layer, and anions and some water molecules embedded in the layers to form a layered structure. LDHs provide an easy regulation of physical and chemical properties and rich hydroxyl groups $[9,10]$. Because the laminated surface of LDHs is rich in hydroxyl groups, it can form hydrogen bonds with many hydroxyl groups in bamboo products and can be easily attached to bamboo [11]. Therefore, the use of LDHs is a novel method for overcoming the shortcomings of water-based inorganic flame retardants.

The coprecipitation method is a simple and commonly used method to prepare LDHs flame retardant materials [12-14]. LDHs with a certain morphology can be prepared at low temperatures by using a simple preparation process. The hydrotalcite product exhibits excellent crystallinity and regular layered structure $[15,16]$, which is beneficial to obtain hydrotalcite with high thermal stability. Because calcium and silicon reserves are abundant, they are cheap [17]. Therefore, the addition of silicate into calcium and aluminium to prepare calcium and aluminium hydrotalcite with a root cutting silicate layer is not only inexpensive but also results in a product with high thermal stability. Thus, hydrotalcite with excellent flame retardant property can be prepared. Therefore, calcium-aluminium hydrotalcite in root cutting silicate layers $\left(\mathrm{CaAl}-\mathrm{SiO}_{3}-\mathrm{LDHs}\right)$ was prepared using the coprecipitation method and it was used as a flame retardant for bamboo to improve the flame retardant performance of bamboo. The effects of preparation technology on the structure and properties of calcium-aluminium hydrotalcite in root cutting silicate layer and the flame retardant and smoke suppression properties of bamboo treated by $\mathrm{CaAl}-\mathrm{SiO}_{3}-\mathrm{LDHs}$ [18] were investigated. The results of this study can provide a reference for the research on new flame retardants for bamboo products.

\section{Materials and Methods}

\subsection{Materials}

Calcium nitrate $\left(\mathrm{Ca}\left(\mathrm{NO}_{3}\right)_{2} \cdot 4 \mathrm{H}_{2} \mathrm{O}\right)$, aluminium nitrate $\left(\mathrm{Al}\left(\mathrm{NO}_{3}\right)_{3} \cdot 9 \mathrm{H}_{2} \mathrm{O}\right)$, sodium silicate $\left(\mathrm{Na}_{2} \mathrm{SiO}_{3} \cdot 9 \mathrm{H}_{2} \mathrm{O}\right)$ and sodium hydroxide $(\mathrm{NaOH})$ were obtained from Sinopharm Chemical Reagent Co., Ltd., Shanghai, China. Deionised water was used in the synthesis and washing process. The water was boiled and cooled to room temperature for reuse.

\subsection{Preparation of The $\mathrm{CaAl}-\mathrm{SiO}_{3}-\mathrm{LDHs}$}

The general formula of hydrotalcite is $\left[\mathrm{M}_{1-x}^{2+} \mathrm{M}_{x}^{3+}(\mathrm{OH})_{2}\right]\left(A_{x / n}^{n-}\right) \cdot m \mathrm{H}_{2} \mathrm{O}$, where $\mathrm{M}$ refers to layered cation, A refers to $n$-valent interlayer anion, and $x=n M^{2+} / n\left[M^{2+}+M^{3+}\right]$, $0.16<x<0.33$ [19]. $\mathrm{Ca}\left(\mathrm{NO}_{3}\right)_{2} \cdot 4 \mathrm{H}_{2} \mathrm{O}$ and $\mathrm{Al}\left(\mathrm{NO}_{3}\right)_{3} \cdot 9 \mathrm{H}_{2} \mathrm{O}$ were weighed and added in the molar ratio of $\mathrm{Ca}^{2+}: \mathrm{Al}^{3+}=2$ [20-22]. A certain amount of deionised water was added, and the mixture was dissolved in a beaker to prepare a mixed salt solution. A corresponding amount of $\mathrm{Na}_{2} \mathrm{SiO}_{3} \cdot 9 \mathrm{H}_{2} \mathrm{O}$ was weighed and added to deionised water. $\mathrm{Ca}^{2+}$ solutions with molar concentrations of $0.13,0.33,0.53$ and $0.73 \mathrm{~mol} / \mathrm{L}$ were prepared. A high-concentration $\mathrm{NaOH}$ solution was prepared for subsequent use. The sodium silicate solution was added to a $500 \mathrm{~mL}$ three-neck flask. The flask was placed in a constant temperature oil bath at $25^{\circ} \mathrm{C}$, and the mixture was stirred. The prepared mixed salt solution and $\mathrm{NaOH}$ solution were subjected to a constant pressure dropping funnel. The $\mathrm{NaOH}$ solution was added until the $\mathrm{pH}$ of the solution in the flask reached 10. Next, the mixed salt solution was added to maintain the $\mathrm{pH}$ value of the solution at 10 . The prepared white slurry was crystallised at 85,100 and $120^{\circ} \mathrm{C}$ and stirred vigorously at a constant speed for 6,9 and $12 \mathrm{~h}$ and subsequently stored at room temperature. Finally, the cake was filtered, washed to neutrality and dried for $24 \mathrm{~h}$ at $80^{\circ} \mathrm{C}$. The synthesis mechanism is illustrated in Figure 1 and the summary table about experimental samples is shown in Table 1. 

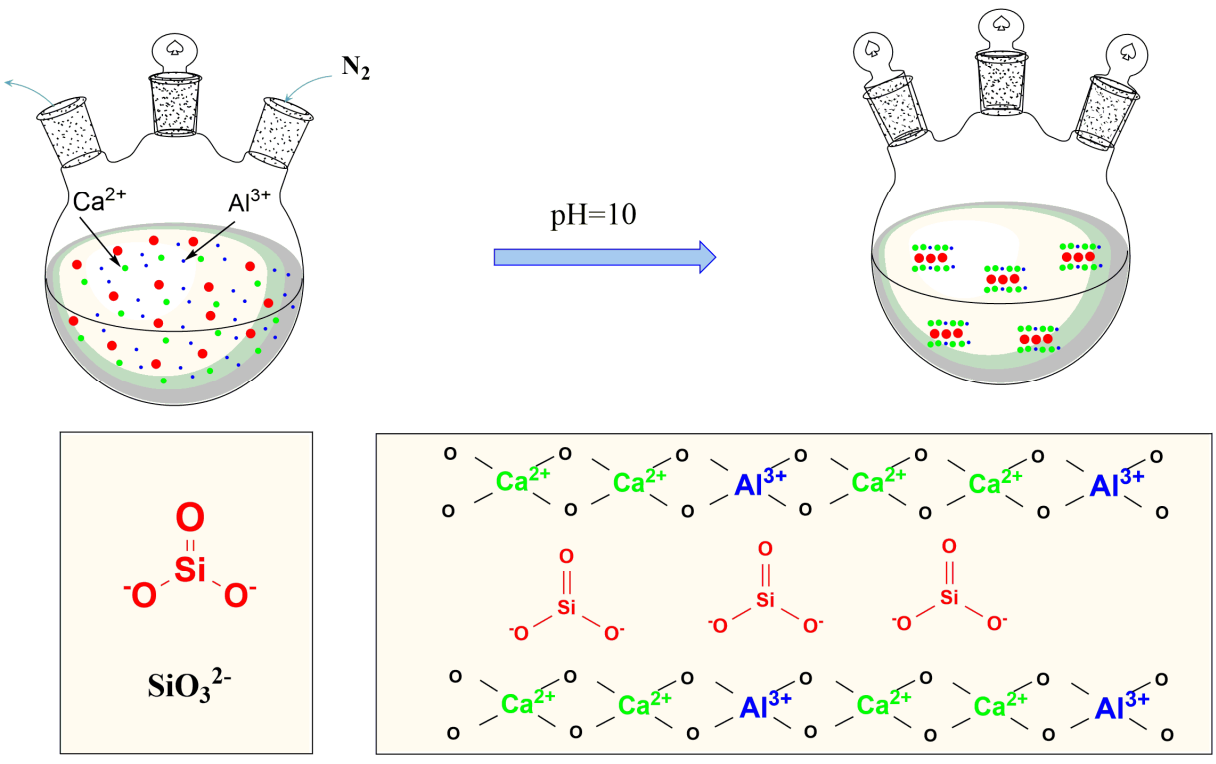

Figure 1. Schematic diagram of synthesis mechanism of $\mathrm{CaAl}-\mathrm{SiO}_{3}-\mathrm{LDHs}$.

Table 1. Summary of experimental samples.

\begin{tabular}{ccccc}
\hline & Sample Number & $\begin{array}{c}\text { Crystallisation } \\
\text { Temperatures }\end{array}$ & Crystallisation Times & $\begin{array}{c}\text { Ca }{ }^{2+} \text { Molar } \\
\text { Concentrations }\end{array}$ \\
\hline $\begin{array}{c}\text { Samples prepared at } \\
\text { different crystallisation }\end{array}$ & $(1)$ & $85^{\circ} \mathrm{C}$ & $12 \mathrm{~h}$ & $0.33 \mathrm{~mol} / \mathrm{L}$ \\
temperatures & $(2)$ & $100^{\circ} \mathrm{C}$ & $12 \mathrm{~h}$ & $0.33 \mathrm{~mol} / \mathrm{L}$ \\
\hline Samples prepared at & $(3)$ & $120^{\circ} \mathrm{C}$ & $12 \mathrm{~h}$ & $0.33 \mathrm{~mol} / \mathrm{L}$ \\
different crystallisation & $(4)$ & $100^{\circ} \mathrm{C}$ & $6 \mathrm{~h}$ & $0.33 \mathrm{~mol} / \mathrm{L}$ \\
times & 5 & $100^{\circ} \mathrm{C}$ & $9 \mathrm{~h}$ & $0.33 \mathrm{~mol} / \mathrm{L}$ \\
\hline & $(6$ & $100^{\circ} \mathrm{C}$ & $12 \mathrm{~h}$ & $0.33 \mathrm{~mol} / \mathrm{L}$ \\
Samples prepared at & $(7$ & $100^{\circ} \mathrm{C}$ & $9 \mathrm{~h}$ & $0.13 \mathrm{~mol} / \mathrm{L}$ \\
different Ca ${ }^{2+}$ molar & 8 & $100^{\circ} \mathrm{C}$ & $9 \mathrm{~h}$ & $0.33 \mathrm{~mol} / \mathrm{L}$ \\
concentrations & $(9)$ & $100^{\circ} \mathrm{C}$ & $9 \mathrm{~h}$ & $0.53 \mathrm{~mol} / \mathrm{L}$ \\
\hline
\end{tabular}

\section{3. $\mathrm{CaAl}-\mathrm{SiO}_{3}-\mathrm{LDH}$ S Flame-Retardant Treated Bamboo}

$\mathrm{A} \mathrm{CaAl}-\mathrm{SiO}_{3}-\mathrm{LDH}$ powder was prepared and ultrasonically dispersed in an aqueous solution to obtain $1 \%$ suspension, and ultrasonic treatment was performed for $1 \mathrm{~h}$. Then, bamboo chips were placed in the $\mathrm{CaAl}-\mathrm{SiO}_{3}-\mathrm{LDH}$ suspension. $\mathrm{Next}$, the $\mathrm{CaAl}-\mathrm{SiO}_{3}-\mathrm{LDH}$ suspension soaked with bamboo chips is placed in a pressurised tank and sealed. Then samples were vacuumised, and when the vacuum degree reaches $0.085 \mathrm{MPa}$, kept for $20 \mathrm{~min}$. Next, a pressure of 0.6 MPa was applied. When the pressure reached the preset value, the exhaust valve was opened to relieve the pressure to the preset value. The bamboo pieces were soaked for $3 \mathrm{~h}$. Finally, the bamboo chips were removed, the suspension on the surface was removed with deionised water and bamboo chips were dried in an oven to obtain $\mathrm{CaAl}-\mathrm{SiO}_{3}-\mathrm{LDH}$ flame-retardant bamboo.

\subsection{Analysis and Testing}

\subsubsection{X-ray Diffraction (XRD) Analysis}

XRD-6000 manufactured by Shimadzu Corporation of Japan was used to analyse the phase composition and crystallisation of the $\mathrm{CaAl}-\mathrm{SiO}_{3}-\mathrm{LDHs}$ samples. The X-ray tube was the $\mathrm{Cu}$ target, $\mathrm{K} \alpha$ was the radiation source, the tube voltage was $40 \mathrm{Kv}$, the tube current was $30 \mathrm{~mA}$, the scanning range was $5^{\circ}-75^{\circ}(2 \theta)$, and the scanning speed was $2^{\circ} / \mathrm{min}$. 


\subsubsection{Fourier Infrared Spectrum (FT-IR) Analysis}

To determine the chemical composition of $\mathrm{CaAl}-\mathrm{SiO}_{3}-\mathrm{LDHs}$ prepared under different conditions, the samples dried in the oven at $80^{\circ} \mathrm{C}$ were mixed and ground with potassium bromide in a ratio of 1:100. The synthesised $\mathrm{CaAl}-\mathrm{SiO}_{3}-\mathrm{LDH}$ samples were analysed using the Prestige-21 FT-IR spectrometer produced by Shimadzu Corporation of Japan, with a scanning range of $400-4000 \mathrm{~cm}^{-1}$.

\subsubsection{Cold Field Emission Scanning Electron Microscopy (SEM) Analysis}

The morphology and dispersion of $\mathrm{CaAl}-\mathrm{SiO}_{3}-\mathrm{LDHs}$ prepared under different conditions were analysed. Cold field emission scanning electron microscope SU8010 produced by Hitachi of Japan was used to analyse $\mathrm{CaAl}-\mathrm{SiO}_{3}-\mathrm{LDHs}$ under an accelerating voltage of $25.0 \mathrm{kV}$.

\subsubsection{Thermogravimetry (TG-DTG) Analysis}

The thermal stability of $\mathrm{CaAl}-\mathrm{SiO}_{3}-\mathrm{LDHs}$ samples was analysed by using the STA 409C thermogravimetric analyser produced by NETZSCH, Germany. The temperature ranged from 35 to $750{ }^{\circ} \mathrm{C}$, the heating rate was $20^{\circ} \mathrm{C} / \mathrm{min}$, the sample mass was 6 to $9 \mathrm{mg}$ and during the reaction process, nitrogen is always introduced.

\subsubsection{Cone Calorimeter (CONE) Analysis}

Nonflame-retardant bamboo chips and flame-retardant treaded bamboo chips were bonded with a small amount of white latex into samples with dimensions of $100 \mathrm{~mm}$ $\times 100 \mathrm{~mm} \times 5 \mathrm{~mm}$ (length $\times$ width $\times$ thickness); the combustion performance of the samples was tested with a cone calorimeter (Fire Testing Technology Ltd., East Grinstead, UK), according to the ISO5660-1 procedure. This is to analyse the influences of CaAl-SiO3-LDHs-flame retardants on the flame-retardant effect of bamboo. The heat radiation power was $50 \mathrm{~kW} / \mathrm{m}^{-2}$, corresponding to temperature of $728^{\circ} \mathrm{C}[23,24]$. During the experiment, with the exception of the heated surface, all five surfaces of the sample were coated with a tin foil, and subsequently placed into a stainless steel mould box. The sample surface was fixed with barbed wire, and the bottom of the sample was sealed with an asbestos pad. The experimental data were collected, processed and analysed using special cone calorimeter software.

\section{Results}

3.1. Effects of Crystallisation Temperature on Structure and Properties of $\mathrm{CaAl}-\mathrm{SiO}_{3}-\mathrm{LDHs}$

The XRD pattern of $\mathrm{CaAl}-\mathrm{SiO}_{3}-\mathrm{LDHs}$ prepared by the crystallisation reaction at 85 , 100 and $120^{\circ} \mathrm{C}$ for $12 \mathrm{~h}$ is displayed in Figure 2.

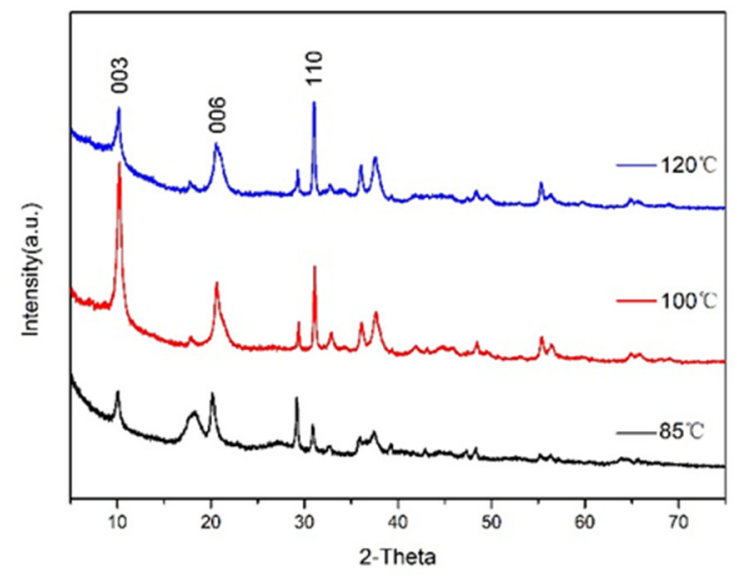

Figure 2. XRD patterns of $\mathrm{CaAl}-\mathrm{SiO}_{3}-\mathrm{LDH}$ prepared at different crystallisation temperatures. 
Several main characteristic peaks of $\mathrm{CaAl}-\mathrm{SiO}_{3}-\mathrm{LDHs}$ samples synthesised at 85 , 100 and $120^{\circ} \mathrm{C}$ corresponded to the characteristic crystal planes (003), (006) and (110) of hydrotalcite. The XRD patterns characteristic peak of $\mathrm{CaAl}-\mathrm{SiO}_{3}-\mathrm{LDH}$ crystallised at $100{ }^{\circ} \mathrm{C}$ was the sharpest, and its intensity was the highest, which indicated that the crystal lattice of the sample was the most complete, and the crystallinity was the highest. Therefore, $100{ }^{\circ} \mathrm{C}$ is the best crystallisation temperature of $\mathrm{CaAl}-\mathrm{SiO}_{3}-\mathrm{LDH}$.

The FT-IR spectra of $\mathrm{CaAl}-\mathrm{SiO}_{3}-\mathrm{LDHs}$ prepared at various crystallisation temperatures are displayed in Figure 3.

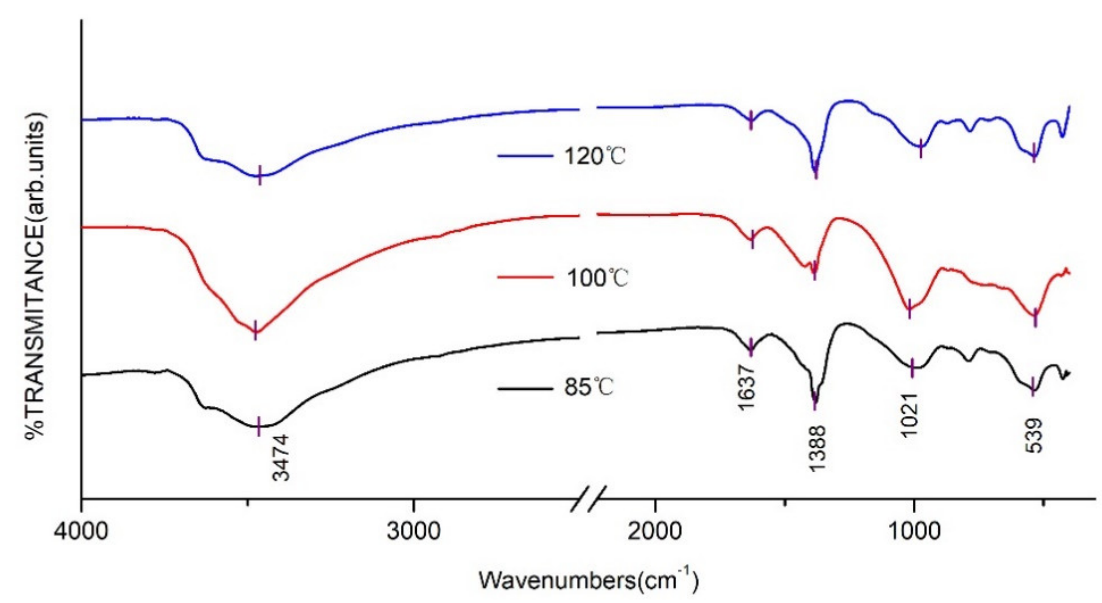

Figure 3. FT-IR spectrum of $\mathrm{CaAl}-\mathrm{SiO}_{3}-\mathrm{LDH}$ prepared at different crystallisation temperatures.

Figure 3 reveals that the FT-IR absorption peaks of $\mathrm{CaAl}-\mathrm{SiO}_{3}-\mathrm{LDH}$ prepared at various crystallisation temperatures are similar. The absorption peak near $3474 \mathrm{~cm}^{-1}$ was related to the stretching vibration of hydroxyl groups of silicate calcium-aluminium hydrotalcite laminate or hydroxyl groups that physically adsorb water molecules. The absorption peak near $1637 \mathrm{~cm}^{-1}$ was caused by the tensile vibration of hydroxyl groups in crystallised water. The absorption peaks at 1021 and $539 \mathrm{~cm}^{-1}$ were caused by the vibration of silicate ions [25], which indicated that silicate was successfully embedded into hydrotalcite. The appearance of the shoulder peak at $1388 \mathrm{~cm}^{-1}$ was attributed to $\mathrm{CO}_{3}{ }^{2-}$, which indicated that $\mathrm{CO}_{3}{ }^{2-}$ was doped in hydrotalcite, which could be related to the strong adsorption capacity of calcium-aluminium hydrotalcite for $\mathrm{CO}_{2}$ caused by the adsorption of $\mathrm{CO}_{2}$ when the sample was exposed to air after preparation [26].

The SEM images of $\mathrm{CaAl}-\mathrm{SiO}_{3}-\mathrm{LDHs}$ prepared at crystallisation temperatures of 85, 100 and $120{ }^{\circ} \mathrm{C}$ are displayed in Figure 4.

Figure 4 reveals that all the $\mathrm{CaAl}-\mathrm{SiO}_{3}-\mathrm{LDHs}$ samples exhibit obvious layered structure, which shows the characteristic structure of hydrotalcite. The samples prepared at crystallisation temperatures of $85^{\circ} \mathrm{C}$ and $100{ }^{\circ} \mathrm{C}$ were unevenly distributed and exhibited two morphologies, namely larger lamellar and smaller lamellar. But the samples prepared at crystallisation temperatures of $85^{\circ} \mathrm{C}$, the smaller lamellar structure was present in a larger proportion; among the samples prepared at $100^{\circ} \mathrm{C}$, the smaller layered structure accounts for a large proportion. However, the samples prepared at $120^{\circ} \mathrm{C}$ exhibited a uniform morphology distribution, but its lamellar size was typically large.

The TG-DTG curves of $\mathrm{CaAl}-\mathrm{SiO}_{3}-\mathrm{LDHs}$ samples prepared at various crystallisation temperatures are displayed in Figure 5.

Thermal weightlessness can be clearly categorised into three weightless stages (Figure 5). The first weight loss stage was attributed to the loss of water molecules and physically adsorbed water in the interlayer of the sample. The second weight loss stage was attributed to the detachment of cationic lamellar hydroxyl groups in the sample and the third weight loss stage was attributed to the pyrolysis of interlayer anions in the sample [27]. In the first weight loss stage, the weight loss rate, maximum weight loss rate and temperature to reach the maximum weight loss rate of the three samples were similar, indicating that 
the amounts of crystal water and adsorbed water of the three samples were similar. In the second weight loss stage, the thermal weight loss of $\mathrm{CaAl}-\mathrm{SiO}_{3}-\mathrm{LDHs}$ samples crystallised at $85{ }^{\circ} \mathrm{C}$ occurred at $165-299{ }^{\circ} \mathrm{C}$, with a weight loss rate of $13 \%$. The weight loss rate and weight loss temperature of the samples crystallised at $85^{\circ} \mathrm{C}$ were higher and lower, respectively, than the other two samples, which indicated that the layered structure was unstable and numerous hydroxyl groups were lost. In the third stage of thermal weight loss, the $\mathrm{CaAl}-\mathrm{SiO}_{3}-\mathrm{LDHs}$ samples crystallised at $100{ }^{\circ} \mathrm{C}$ exhibited thermal weight loss at $480-564{ }^{\circ} \mathrm{C}$, with a weight loss rate of $5 \%$. Weight loss temperature, the weight loss peak and the thermal stability of the $\mathrm{CaAl}-\mathrm{SiO}_{3}-\mathrm{LDHs}$ samples crystallised at $100{ }^{\circ} \mathrm{C}$ were higher, narrower and better than those of the other samples. Therefore, the composition and distribution of interlayer anions in $\mathrm{CaAl}-\mathrm{SiO}_{3}-\mathrm{LDH}$ samples crystallised at $100{ }^{\circ} \mathrm{C}$ were uniform. Thus, $100{ }^{\circ} \mathrm{C}$ was the best crystallisation temperature for preparing $\mathrm{CaAl}-$ $\mathrm{SiO}_{3}-\mathrm{LDH}$.

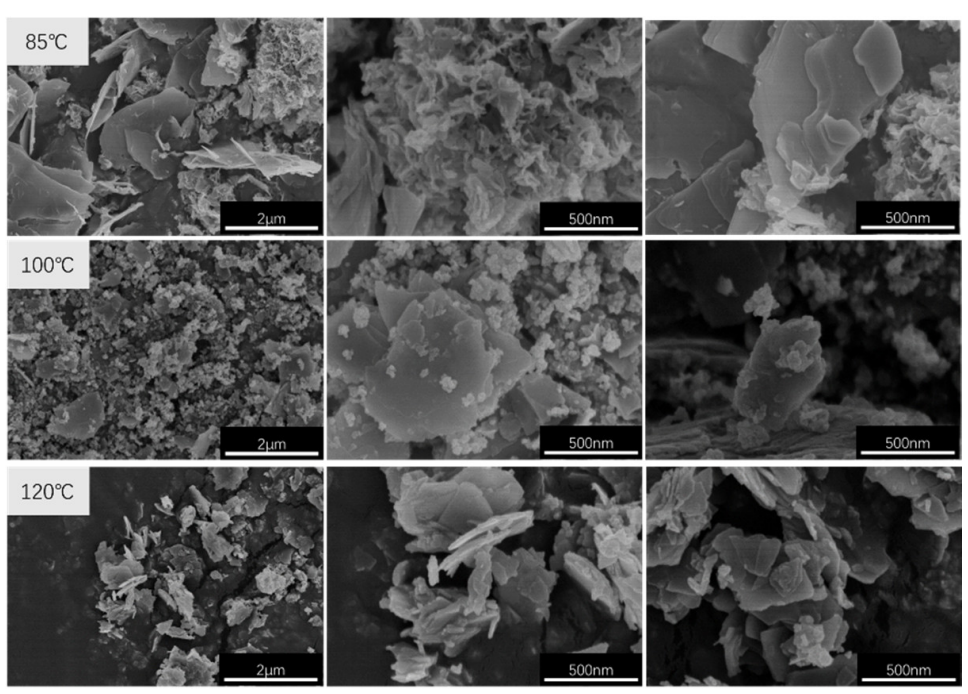

Figure 4. SEM images of $\mathrm{CaAl}-\mathrm{SiO}_{3}-\mathrm{LDH}$ samples prepared at different crystallisation temperatures.

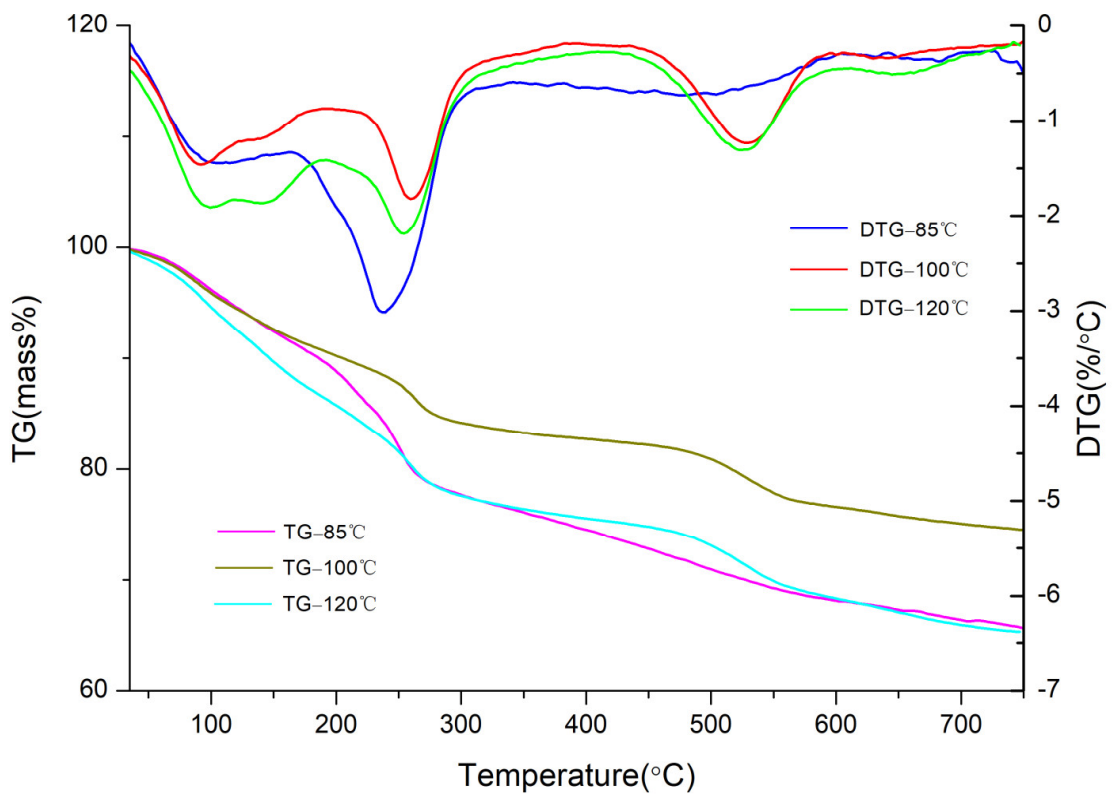

Figure 5. TG-DTG image of $\mathrm{CaAl}-\mathrm{SiO}_{3}-\mathrm{LDH}$ samples prepared at different crystallisation temperatures. 


\subsection{Effect of the Crystallisation Time on the Structure and Properties of $\mathrm{CaAl}-\mathrm{SiO}_{3}-\mathrm{LDHs}$}

The XRD patterns of $\mathrm{CaAl}-\mathrm{SiO}_{3}-\mathrm{LDH}$ prepared by crystallisation reaction at $100{ }^{\circ} \mathrm{C}$ for 6,9 and $12 \mathrm{~h}$ are displayed in Figure 6.

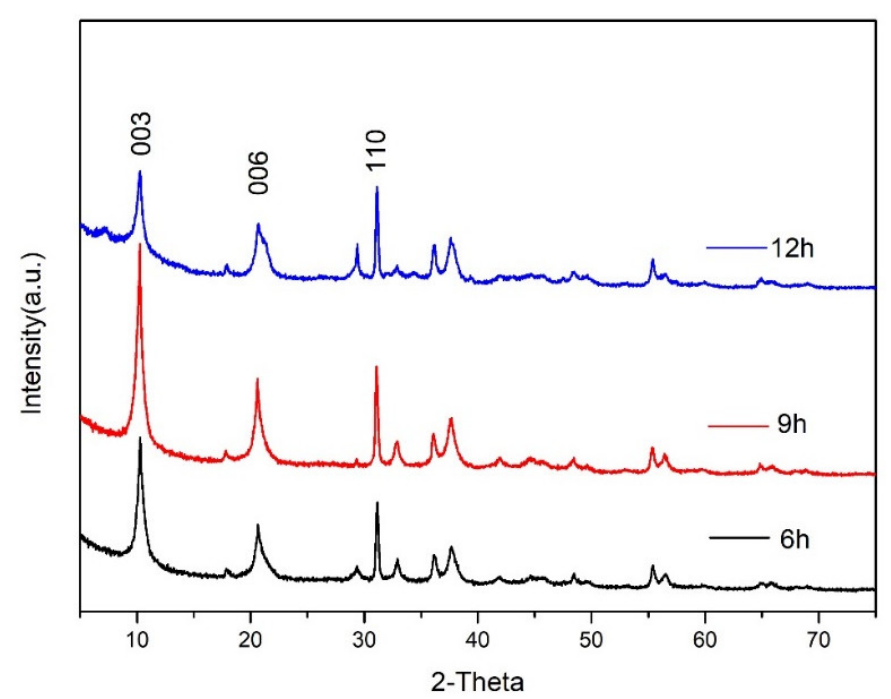

Figure 6. XRD patterns of $\mathrm{CaAl}-\mathrm{SiO}_{3}-\mathrm{LDH}$ prepared at different crystallisation time.

Figure 6 reveals that the main characteristic peaks of the synthesised $\mathrm{CaAl}-\mathrm{SiO}_{3}-\mathrm{LDHs}$ sample are similar to the characteristic crystal planes (003), (006) and (110) of hydrotalcite. This phenomenon indicated that the synthesised sample has a typical hydrotalcite lattice structure. The difference in location of each characteristic crystal plane between various samples was not more than 0.2 , which indicated that the crystal lattice structure of the synthesised samples was stable when the crystallisation temperature was $100{ }^{\circ} \mathrm{C}$, proving that $100{ }^{\circ} \mathrm{C}$ was the best crystallisation temperature for synthesising $\mathrm{CaAl}-\mathrm{SiO}_{3}-\mathrm{LDHs}$. Among all the samples, the XRD characteristic peaks intensity of the samples with crystallisation time of $9 \mathrm{~h}$ was the highest and sharpest, which indicated that the samples with the crystallisation time of $9 \mathrm{~h}$ exhibited the highest crystallinity.

The FT-IR spectra of $\mathrm{CaAl}-\mathrm{SiO}_{3}-\mathrm{LDHs}$ prepared by crystallisation reaction at $100{ }^{\circ} \mathrm{C}$ for 6,9 and $12 \mathrm{~h}$ are displayed in Figure 7.

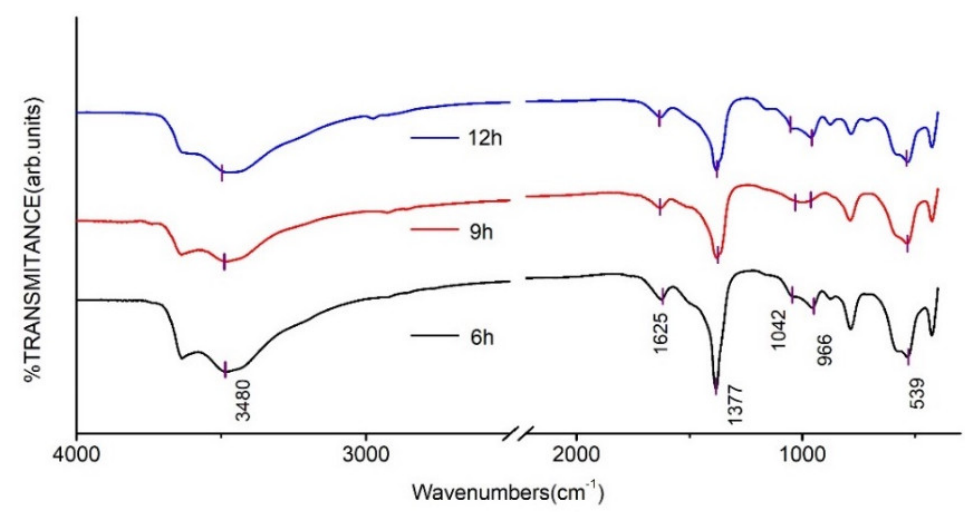

Figure 7. FT-IR spectrum of $\mathrm{CaAl}-\mathrm{SiO}_{3}-\mathrm{LDHs}$ prepared at different crystallisation time.

The FT-IR absorption peaks of several $\mathrm{CaAl}-\mathrm{SiO}_{3}-\mathrm{LDH}$ samples were similar (Figure 7). The absorption peak near $3480 \mathrm{~cm}^{-1}$ was related to the stretching vibration of hydroxyl groups in silicate calcium-aluminium hydrotalcite laminate or hydroxyl groups that physically adsorbed water molecules, whereas the absorption peak near $1625 \mathrm{~cm}^{-1}$ was caused by the stretching vibration of hydroxyl groups in crystallised water. The peaks at 1042-966 and $539 \mathrm{~cm}^{-1}$ were caused by the vibration of silicate ions, which indicated that silicate 
was successfully embedded in hydrotalcite. The peak of tensile vibration of $\mathrm{CO}$ appeared at $1377 \mathrm{~cm}^{-1}$, which indicated that the hydrotalcite was doped with $\mathrm{CO}_{3}{ }^{2-}$ and could be related to the strong adsorption capacity of calcium-aluminium hydrotalcite for $\mathrm{CO}_{2}$ caused by the adsorption of $\mathrm{CO}_{2}$ after the sample was prepared and exposed to air.

The SEM images of the $\mathrm{CaAl}-\mathrm{SiO}_{3}-\mathrm{LDH}$ samples prepared at $100{ }^{\circ} \mathrm{C}$ and various crystallisation times are displayed in Figure 8.

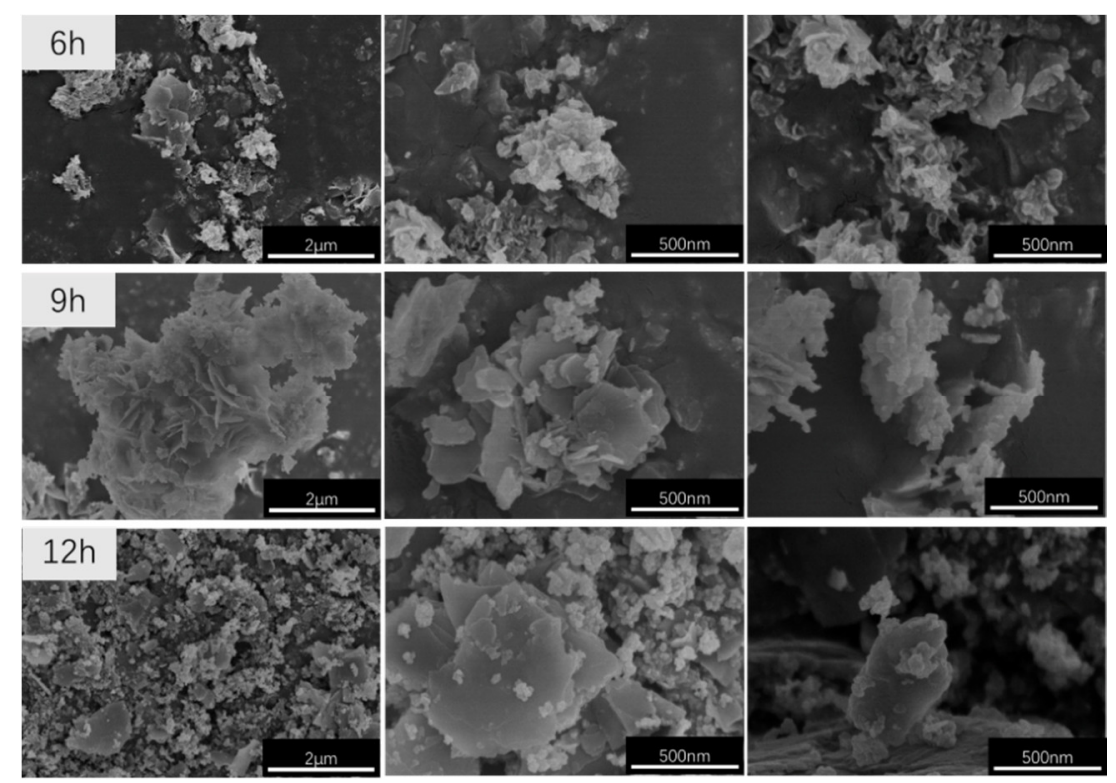

Figure 8. SEM images of $\mathrm{CaAl}-\mathrm{SiO}_{3}-\mathrm{LDHs}$ samples prepared at different crystallisation time.

Figure 8 reveals that every $\mathrm{CaAl}-\mathrm{SiO}_{3}-\mathrm{LDH}$ sample exhibits an obvious layered structure. Among them, the samples prepared at crystallisation times of 6 and $12 \mathrm{~h}$ were not uniform in morphology and exhibited two or more large-layered structures, namely larger- and smaller-layered structures. Furthermore, the sizes of various layered structures differed considerably, and some even varied by $>10$ times. However, when the crystallisation time was $9 \mathrm{~h}$, the morphology of $\mathrm{CaAl}-\mathrm{SiO}_{3}-\mathrm{LDHs}$ samples was uniform and exhibited almost no difference. Therefore, the crystallisation time of $9 \mathrm{~h}$ was the best time for the preparation of $\mathrm{CaAl}-\mathrm{SiO}_{3}-\mathrm{LDHs}$.

The TG-DTG curves of $\mathrm{CaAl}_{-} \mathrm{SiO}_{3}-\mathrm{LDH}$ samples prepared at crystallisation times of 6,9 and $12 \mathrm{~h}$ respectively, are displayed in Figure 9.

Figure 9 reveals that the thermal weight loss of $\mathrm{CaAl}-\mathrm{SiO}_{3}-\mathrm{LDH}$ samples prepared at various crystallisation times can be categorised into three stages, which indicated that the thermal weight loss law of the prepared samples conformed to the three-stage thermal weight loss law of hydrotalcite, in which the sample prepared after crystallisation for $6 \mathrm{~h}$ exhibited the smallest weight loss, whereas those prepared after crystallisation for $9 \mathrm{~h} \mathrm{ex}-$ hibited the largest weight loss and the weight loss in the second and third stages was higher than that in other stages. The relative contents of $-\mathrm{OH}$ and anions in $\mathrm{CaAl}-\mathrm{SiO}_{3}-\mathrm{LDH}$ samples were higher in the samples crystallised for $9 \mathrm{~h}$ than those in other samples. The weight loss peak of the DTG curve of the sample prepared by crystallisation for $9 \mathrm{~h}$ was the narrowest, which indicated that the sample were uniform [28], thus verifying the conclusions of SEM images. Moreover, the sample prepared by crystallisation for $9 \mathrm{~h}$ exhibited a slightly higher thermal loss temperature than other sample, which indicated their thermal stability was good. Thus, when $\mathrm{CaAl}-\mathrm{SiO}_{3}-\mathrm{LDH}$ was prepared by the coprecipitation method, the best crystallisation time is $9 \mathrm{~h}$. 


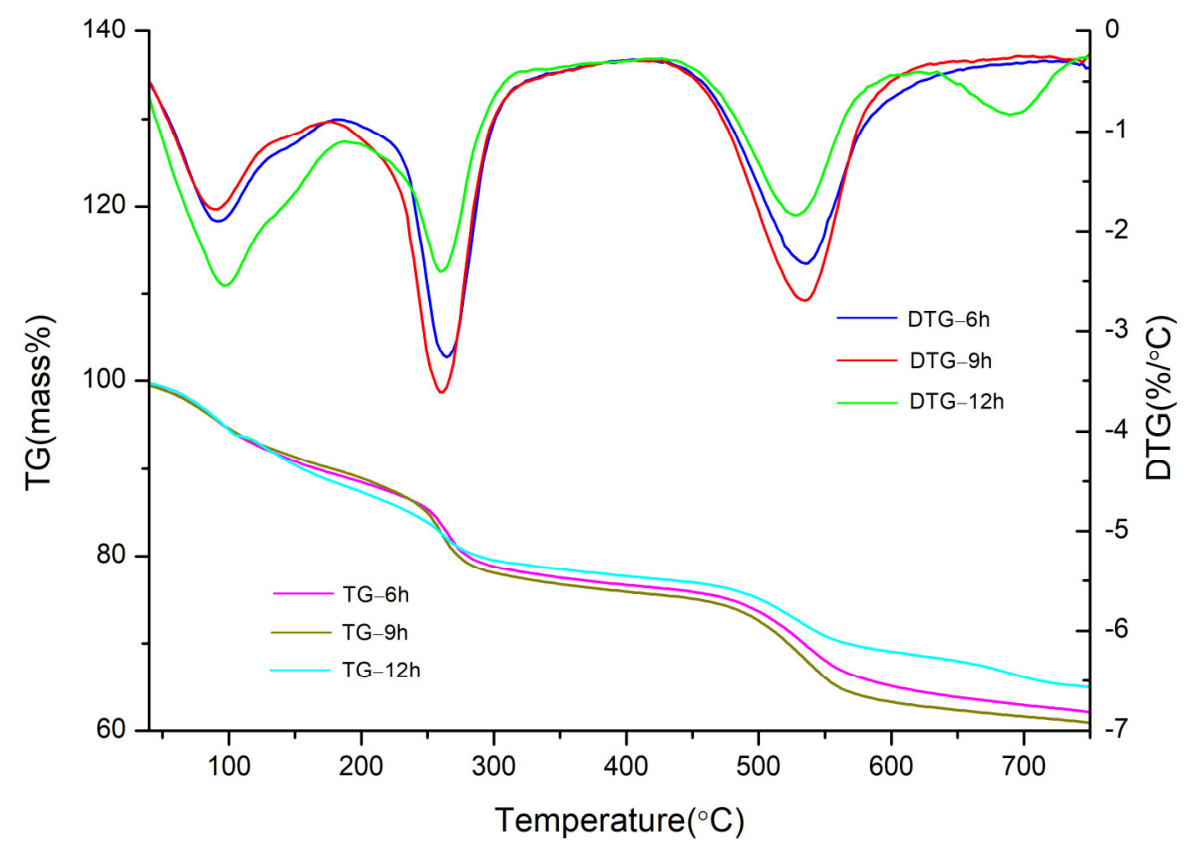

Figure 9. TG-DTG of $\mathrm{CaAl}-\mathrm{SiO}_{3}-\mathrm{LDHs}$ samples prepared at different crystallisation time.

3.3. Effect of the Crystallisation Concentration on the Structure and Properties of $\mathrm{CaAl}-\mathrm{SiO}_{3}-\mathrm{LDHs}$

The effects of $\mathrm{Ca}^{2+}$ molar concentrations of $0.13,0.33,0.53$ and $0.73 \mathrm{~mol} / \mathrm{L}$ on $\mathrm{CaAl}-$ $\mathrm{SiO}_{3}-\mathrm{LDH}$ prepared at crystallisation temperature of $100{ }^{\circ} \mathrm{C}$ and a crystallisation time of $9 \mathrm{~h}$ were investigated. The XRD patterns of the prepared samples are displayed in Figure 10.

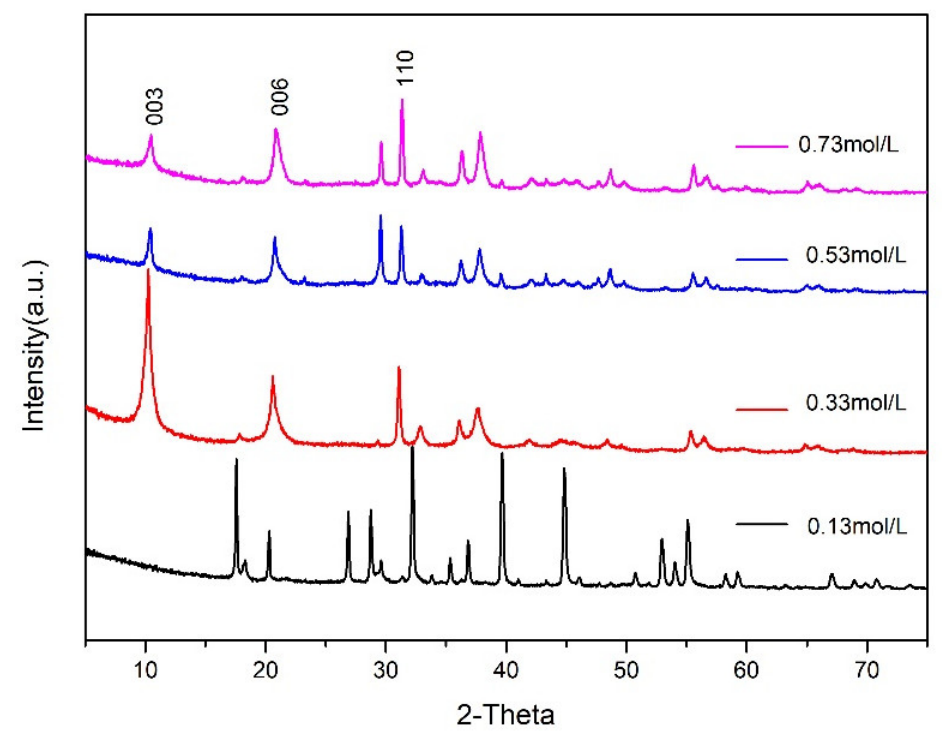

Figure 10. XRD patterns of $\mathrm{CaAl}-\mathrm{SiO}_{3}-\mathrm{LDHs}$ prepared at different $\mathrm{Ca}^{2+}$ molar concentrations.

Figure 10 reveals that structural characteristic peaks of the hydrotalcite samples with $\mathrm{Ca}^{2+}$ molar concentration of $0.13 \mathrm{~mol} / \mathrm{L}$ are not obvious. However, the main characteristic peaks of the $\mathrm{CaAl}-\mathrm{SiO}_{3}-\mathrm{LDH}$ samples with $\mathrm{Ca}^{2+}$ molar concentrations of $0.33,0.53$ and $0.73 \mathrm{~mol} / \mathrm{L}$ differed from the characteristic crystal planes (003), (006) and (110) of hydrotalcite. The XRD patterns of $\mathrm{CaAl}-\mathrm{SiO}_{3}-\mathrm{LDHs}$ synthesised with the molar concentration of $\mathrm{Ca}^{2+}$ of $0.33 \mathrm{~mol} / \mathrm{L}$ exhibited the sharpest characteristic peak and the highest intensity, which indicated that the sample exhibited the most complete lattice and the highest crys- 
tallinity. Therefore, the molar concentration of $\mathrm{Ca}^{2+}$ of $0.33 \mathrm{~mol} / \mathrm{L}$ is the optimal molar concentration for synthesising $\mathrm{CaAl}-\mathrm{SiO}_{3}-\mathrm{LDHs}$. Due to the fact that the sample with the concentration of 0.13 does not have the structural characteristics of hydrotalcite, it will not be further explored.

The FT-IR spectra of $\mathrm{CaAl}-\mathrm{SiO}_{3}-\mathrm{LDH}$ prepared with the molar concentrations of $0.33,0.53$ and $0.73 \mathrm{~mol} / \mathrm{L}$ are displayed in Figure 11.

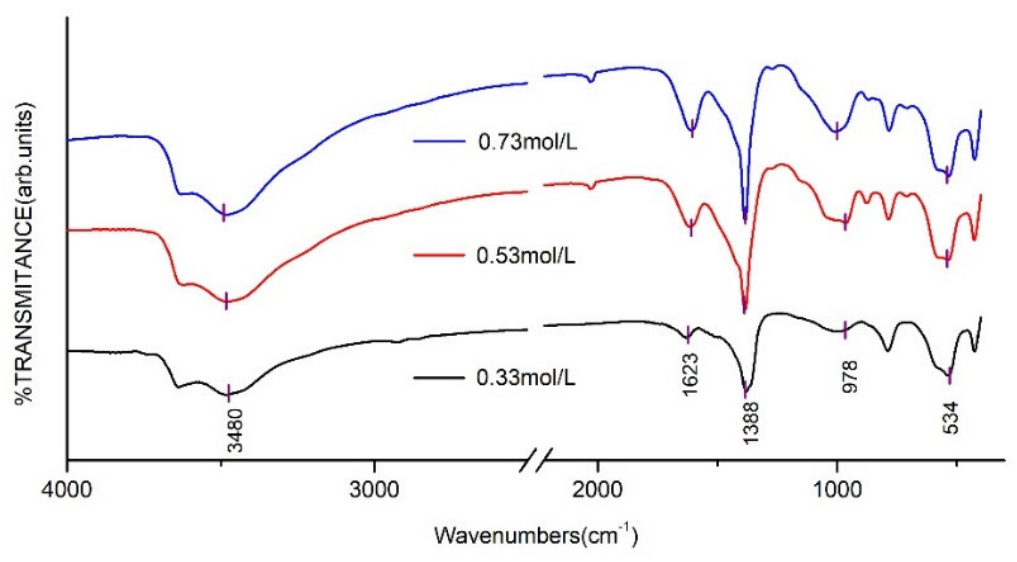

Figure 11. FT-IR spectrum of $\mathrm{CaAl}-\mathrm{SiO}_{3}-\mathrm{LDH}$ prepared at different $\mathrm{Ca}^{2+}$ molar concentrations.

The positions of FT-IR absorption peaks of three $\mathrm{CaAl}-\mathrm{SiO}_{3}-\mathrm{LDHs}$ samples are similar. The absorption peak near $3480 \mathrm{~cm}^{-1}$ was related to the stretching vibration of hydroxyl groups in silicate calcium-aluminium hydrotalcite laminate or hydroxyl groups that physically adsorb water molecules, whereas the absorption peak near $1623 \mathrm{~cm}^{-1}$ was caused by the stretching vibration of hydroxyl groups in crystallised water. The vibration peaks of silicate ions appeared at 978 and $539 \mathrm{~cm}^{-1}$, which indicated that silicate ions were successfully embedded in hydrotalcite. The peak of tensile vibration of $\mathrm{CO}$ appeared at $1388 \mathrm{~cm}^{-1}$, which indicated that $\mathrm{CO}_{3}{ }^{2-}$ was doped in hydrotalcite.

The SEM images of $\mathrm{CaAl}-\mathrm{SiO}_{3}-\mathrm{LDHs}$ prepared with molar concentrations of 0.33 , 0.53 and $0.73 \mathrm{~mol} / \mathrm{L}$ are displayed in Figure 12 .

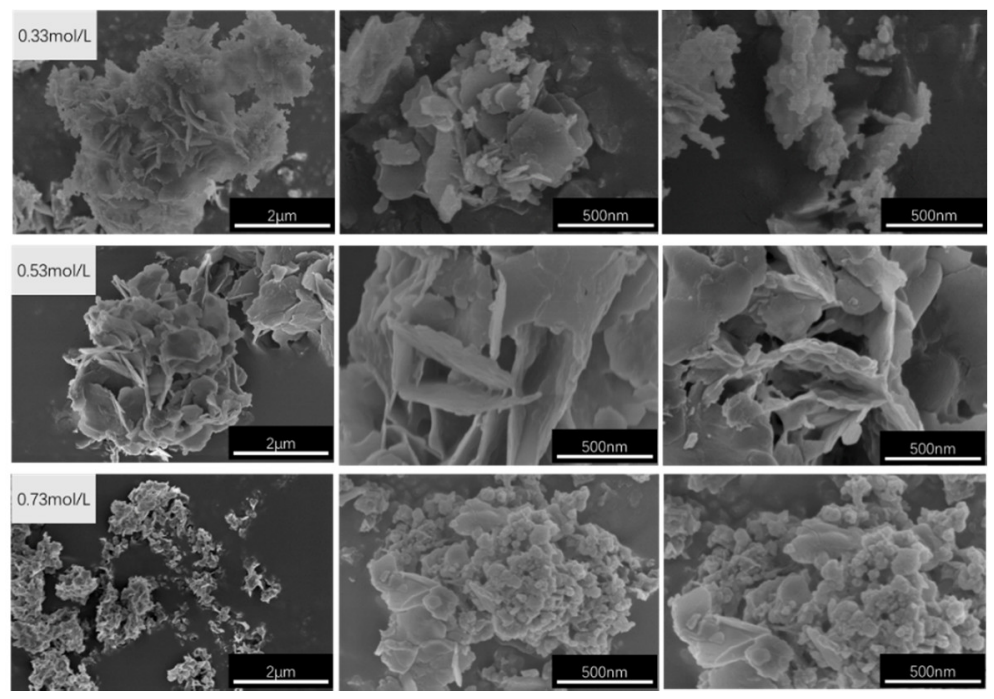

Figure 12. $\mathrm{SEM}$ images of $\mathrm{CaAl}-\mathrm{SiO}_{3}-\mathrm{LDH}$ samples prepared at different $\mathrm{Ca}^{2+}$ molar concentrations.

Figure 12 reveals that the $\mathrm{CaAl}-\mathrm{SiO}_{3}-\mathrm{LDHs}$ samples prepared at concentrations of 0.33 and $0.53 \mathrm{~mol} / \mathrm{L}$ exhibited an obvious layered structure, which is consistent with $\mathrm{XRD}$ analysis results. The sample with the concentration of $0.53 \mathrm{~mol} / \mathrm{L}$ exhibited a uniform appearance, but its size was large. Thus, $0.33 \mathrm{~mol} / \mathrm{L}$ is the best concentration for 
preparing $\mathrm{CaAl}-\mathrm{SiO}_{3}-\mathrm{LDHs}$ because the sample with $0.33 \mathrm{~mol} / \mathrm{L}$ was the most uniform in morphology and size.

The TG-DTG curves of CAl-SiO $3-\mathrm{LDH}$ s prepared with molar concentrations of 0.33 , 0.53 and $0.73 \mathrm{~mol} / \mathrm{L}$ are displayed in Figure 13.

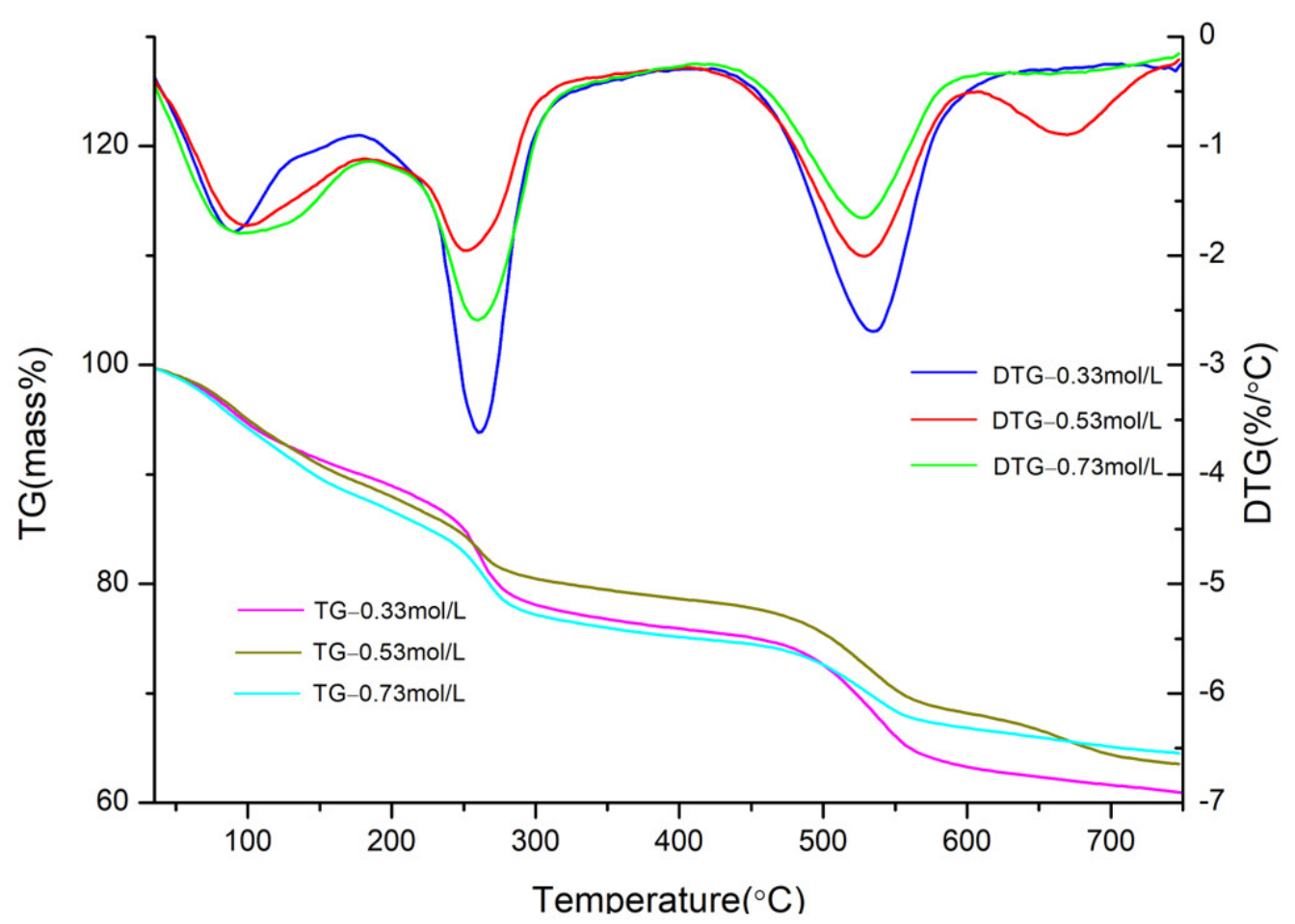

Figure 13. TG-DTG image of $\mathrm{CaAl}-\mathrm{SiO}_{3}-\mathrm{LDHs}$ samples prepared at different $\mathrm{Ca}^{2+}$ molar concentrations.

Figure 13 reveals that the weight loss of samples with molar concentrations of 0.33 , 0.53 and $0.73 \mathrm{~mol} / \mathrm{L}$ can be categorised into three stages, which indicates that the law of weight loss of the prepared samples accords with the law of three-stage weight loss of hydrotalcite. However, the weight loss peak of the DTG curve of the sample prepared with the concentration of $0.33 \mathrm{~mol} / \mathrm{L}$ was the narrowest, which indicated that the sample was more uniform, and its thermal weight loss temperature was slightly higher than that of other samples, and its thermal stability was satisfactory. The optimum $\mathrm{Ca}^{2+}$ concentration for preparing $\mathrm{CaAl}-\mathrm{SiO}_{3}-\mathrm{LDHs}$ by coprecipitation was $0.33 \mathrm{~mol} / \mathrm{L}$.

\subsection{Heat Release Rate (HRR)}

The HRR curves of bamboo before and after flame retardant treatment of $\mathrm{CaAl}-\mathrm{SiO}_{3}-\mathrm{LDHs}$ are displayed in Figure 14.

The HRR of materials during combustion can reflect the speed and magnitude of heat released from a fire source [29]. The larger the HRR is, the more heat is fed back to the surface of the material, which accelerates the pyrolysis of the material, increases the generation of volatile combustible materials and finally accelerates flame propagation. Lowering the HRR can effectively reduce the fire risk of the material. Two HRR peaks can be observed in the burning process of bamboo. Figure 14 reveals the first HRR peak appears at $45 \mathrm{~s}$, and the first HRR peak of flame-retardant wood is $25 \%$ lower than that of nonflame-retardant wood. In nonflame-retardant bamboo chips, the HRR peaks appeared at $125 \mathrm{~s}$. Compared with non-flame-retardant bamboo, and the values of the second HRR peak of treated bamboo decreased by $13.79 \%$, and its arrival time was delayed by $20 \mathrm{~s}$, which indicated that the decomposition or absorption of $\mathrm{CaAl}-\mathrm{SiO}_{3}-\mathrm{LDH}$ reduced the heat generated by bamboo combustion and inhibited bamboo combustion. When the fire 
was at its peak and the $\mathrm{HRR}$ reached its peak, $\mathrm{CaAl}-\mathrm{SiO}_{3}-\mathrm{LDH}$ delayed the arrival time and improved the flame retardancy of bamboo.

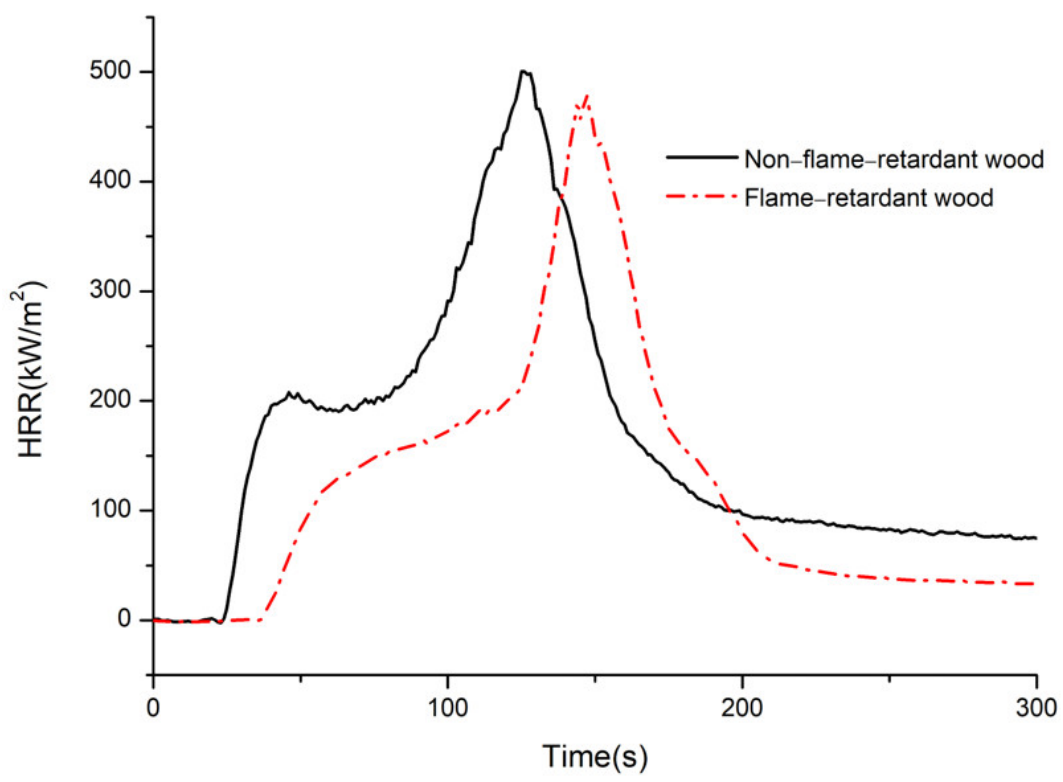

Figure 14. HRR of non-flame retardant bamboo and flame retardant bamboo.

\subsection{Time to Ignition (TTI)}

The TTI refers to the continuous ignition time required for the flame to burn on the material surface. The longer the ignition time is, the less likely ignition occurs under experimental conditions, and the better the flame retardance of the material is [30]. In the cone calorimeter, the ignition time of nonflame-retardant bamboo and bamboo embedded with flame retardant was 18 and $32 \mathrm{~s}$, and the ignition time of flame retardant treated wood was delayed by $77.78 \%$. Therefore, the bamboo embedded with $\mathrm{CaAl}-\mathrm{SiO}_{3}-\mathrm{LDHs}$ did not easily catch fire, and the flame retardant property of bamboo was considerably improved.

\subsection{Mass of Residue(Mass)}

Figure 15 reveals the curve of the residual mass of bamboo before and after flame retardant treatment with $\mathrm{CaAl}-\mathrm{SiO}_{3}-\mathrm{LDHs}$.

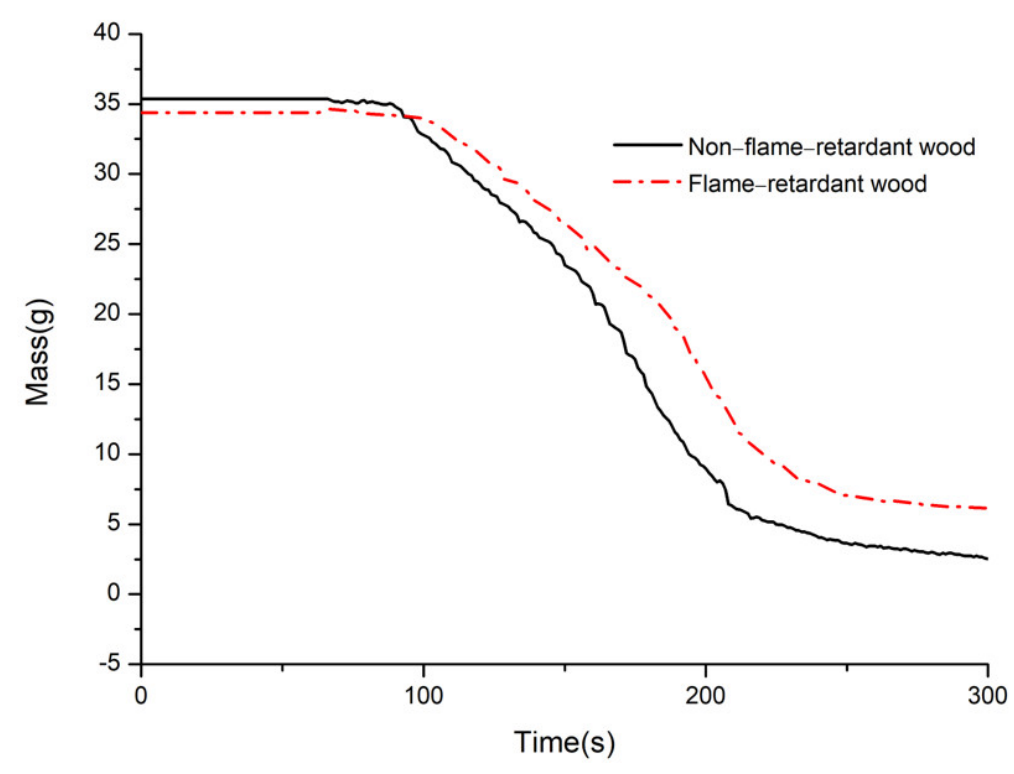

Figure 15. Mass of non-flame retardant bamboo and flame retardant bamboo. 
The final remaining mass of nonflame-retardant bamboo chips accounted for $8 \%$ of the initial mass, whereas that of bamboo chips embedded with flame retardant accounted for $17.54 \%$ of the initial mass. Compared with nonflame-retardant bamboo chips, the residue mass of bamboo after treatment improved by $9.54 \%$, which indicates that the addition of $\mathrm{CaAl}-\mathrm{SiO}_{3}-\mathrm{LDH}$ improved the carbon residue rate of bamboo, such that $\mathrm{CaAl}-\mathrm{SiO}_{3}-\mathrm{LDHs}$ could promote char formation during combustion.

\section{Conclusions}

(1) The crystallisation temperature of $\mathrm{CaAl}-\mathrm{SiO}_{3}-\mathrm{LDHs}$ considerably influenced its structure and properties. The crystallinity and thermal stability of $\mathrm{CaAl}-\mathrm{SiO}_{3}-\mathrm{LDHs}$ prepared at $100{ }^{\circ} \mathrm{C}$ was the highest.

(2) The crystallisation time of $\mathrm{CaAl}-\mathrm{SiO}_{3}-\mathrm{LDH}$ considerably influenced its structure and properties. The sample prepared at $9 \mathrm{~h}$ exhibited high crystallinity, obvious layered structure and the best thermal stability.

(3) The molar concentration of solution of $\mathrm{CaAl}-\mathrm{SiO}_{3}-\mathrm{LDH}$ considerably influenced its structure and properties. When the molar concentration of $\mathrm{Ca}^{2+}$ was $0.33 \mathrm{~mol} / \mathrm{L}$, the crystallinity of the sample was the highest, the lamellar was the most uniform and the thermal stability is excellent.

(4) The optimum technological parameters for preparing $\mathrm{CaAl}-\mathrm{SiO}_{3}-\mathrm{LDHs}$ by the coprecipitation method are as follows: crystallisation temperature $100{ }^{\circ} \mathrm{C}$, crystallisation time $9 \mathrm{~h}$ and molar concentration of $\mathrm{Ca}^{2+}$ solution $0.33 \mathrm{~mol} / \mathrm{L}$. It is not a cheap raw material, but also has high thermal stability.

(5) Compared with the nonflame-retardant bamboo chips, after flame retardant treatment with $\mathrm{CaAl}-\mathrm{SiO}_{3}-\mathrm{LDHs}$, the peak times of $\mathrm{HRR}$ and ignition were delayed by $20 \mathrm{~s}$ and $77.78 \%$, respectively, and the residual carbon rate was increased by $9.54 \%$, the results show that the addition of $\mathrm{CaAl}-\mathrm{SiO}_{3}-\mathrm{LDHs}$ greatly improves the flame retardancy of bamboo.

Author Contributions: Conceptualization, C.D. and H.Y.; methodology, C.D.; software, A.H.; validation, C.L., S.C. and Q.L.; formal analysis, A.H. and Y.H.; investigation, A.H. and Y.H.; resources, H.Y.; data curation, A.H., Y.H. and Y.S.; writing-original draft preparation, A.H.; writing-review and editing, C.D.; visualization, A.H.; supervision, C.D.; project administration, C.D.; funding acquisition, C.D. All authors have read and agreed to the published version of the manuscript.

Funding: This research was funded by Zhejiang Provincial Key Natural Science Foundation Project (LZ17C160001); Zhejiang Provincial Key Research and Development Project (2019C02037).

Data Availability Statement: All data can be found within the manuscript.

Conflicts of Interest: The authors declare no conflict of interest.

\section{References}

1. Zhang, Q. Science and innovation should be emphasized in bamboo processing and utilization in China. J. Zhejiang For. Coll. 2003, 20, 1-4.

2. Zhou, Z.; Du, C.; Wei, J.; Yu, H. General situation and prospect of bamboo flame retardant research. J. Zhejiang For. Sci. Technol. 2016, 36, 71-77.

3. Yao, X.; Du, C.; Hua, Y.; Zhang, J.; Peng, R.; Huang, Q.; Liu, H. Flame-Retardant and Smoke Suppression Properties of Nano MgAl-LDH Coating on Bamboo Prepared by an In Situ Reaction. J. Nanomater. 2019, 2019, 1-12. [CrossRef]

4. Zhou, Z. Study of Water-Based Flame Retardant on Main Properties of Bamboo; Zhejiang A\&F University: Hangzhou, China, 2018.

5. Zhao, Z. Study on the Application of Water-based Flame Retardant in Wood. Secur. Technol. 2010, 8, 39-41.

6. He, W.; Song, P.; Yu, B.; Fang, Z.; Wang, H. Flame retardant polymeric nanocomposites through the combination of nanomaterials and conventional flame retardants. Prog. Mater. Sci. 2020, 114, 100687. [CrossRef]

7. Dhaliwal, G.S.; Bajwa, D.S.; Bajwa, S. Fabrication and Testing of SoyBased Polyurethane Foam with Flame Retardant Properties. J. Polym. Environ. 2020, 29, 1153-1161. [CrossRef]

8. Zhang, D.; Meng, D.; Ma, Z.; Zhang, Z.; Ning, H.; Wang, Y. Synthesis of a novel organic-inorganic hybrid flame retardant based on $\mathrm{Ca}(\mathrm{H} 2 \mathrm{PO} 4) 2$ and hexachlorocyclotriphosphazene and its performance in polyvinyl alcohol. J. Appl. Polym. Sci. 2021, 138, 50099. [CrossRef] 
9. Yang, J.; Xie, G. Research Progress in Polymer/Layered Double Hydroxide Nanocomposites. Synth. Fibre 2014, $43,41-47$.

10. Leão, A.D.; da Silva, L.A.; Ribeiro, F.d.S.; da Silva, D.A.; de França, E.J.; da Silva Aquino, K.A.; Soares-Sobrinho, J.L. Influence of Nonmodified Layered Double Hydroxide (LDH) Metal Constituents in PMMA/LDH Nanocomposites. J. Inorg. Organomet. Polym. Mater. 2021, 31, 836-850. [CrossRef]

11. Hua, Y.; Du, C.; Yu, H.; Hu, A.; Peng, R.; Zhang, J.; Li, Q.; Ma, Z. Flame-retardancy and smoke suppression characteristics of bamboo impregnated with silicate-intercalated calcium aluminum hydrotalcates. Bioresources 2020, 16, 1311-1324. [CrossRef]

12. Damindarova, V.N.; Ryl'tsova, I.G.; Tarasenko, E.A.; Wang, X.; Lebedeva, O.E. Tin-Containing Layered Double Hydroxides. Pet. Chem. 2020, 60, 444-450. [CrossRef]

13. Guo, L.; Zhang, F.; Lu, J.; Zeng, R.; Li, S.; Song, L.; Zeng, J. A comparison of corrosion inhibition of magnesium aluminum and zinc aluminum vanadate intercalated layered double hydroxides on magnesium alloys. Front. Mater. Sci. 2018, 12, 198-206. [CrossRef]

14. Duan, Z.; Zhang, X.; Cheng, N.; Wu, Y.; Qiu, T. Research Progress of Hydrotalcite Materials for Catalytic Dehydrogenation. Fine Chem. Ind. 2021, 1-13. [CrossRef]

15. Tsuyumoto, I. High flame retardancy of amorphous sodium silicate on poly(ethylene-co-vinyl acetate) (EVA). Polym. Bull. 2018, 75, 4967-4976. [CrossRef]

16. Guo, J.; Yin, A.; Chen, J.; Hu, C.; Yi, T.; Shen, X. Different methods to prepare layered hydrotalcite with p-aminobenzenesulfonic acid root cutting. J. Hunan Univ. Humanit. Sci. Technol. 2009, 2, 9-13.

17. Wang, X. Atlas of geochemical element and the basic necessities of life. Pop. Sci. Territ. Resour. Cult. 2016, 3, 4-9.

18. Du, C.; Zhou, Z.; Yu, H.; Huang, Q.; Yao, X.; Jin, C. Smoke toxicity and smoke suppression performance of flame-retardant bamboo during burning. J. Nanjing For. Univ. (Nat. Sci. Ed.) 2017, 41, 163-168.

19. Kovanda, F.; Jindová, E.; Lang, K.; Kubát, P.; Sedláková, Z. Preparation of layered double hydroxides intercalated with organic anions and their application in LDH/poly(butyl methacrylate) nanocomposites. Appl. Clay Sci. 2010, 48, 260-270. [CrossRef]

20. Yanshan, H.; Linhua, Z.; Jin, Y.; Yanlin, S. Structure, properties, preparation and application in catalysis of hydrotalcite-like anionic intercalation materials. Silic. Bull. 2013, 32, 429-433.

21. Chang, P.; Lee, T.; Chang, Y.; Chen, S. $\mathrm{CO}_{2}$ Sorbents with Scaffold-like CaAl Layered Double Hydroxides as Precursors for $\mathrm{CO}_{2}$ Capture at High Temperatures. Chemsuschem 2013, 6, 1076-1083. [CrossRef] [PubMed]

22. Mora, M.; López, M.I.; Jiménez-Sanchidrián, C.; Ruiz, J.R. Ca/Al Mixed Oxides as Catalysts for the Meerwein-Ponndorf-Verley Reaction. Catal. Lett. 2010, 136, 192-198. [CrossRef]

23. Yao, X.; Peng, R.; Du, C.; Hua, Y.; Zhang, J.; Huang, Q.; Liu, H. A Two-step Method for Fabricating Bamboo Culm Coated with MgAl-LDHs and its Fire Resistance Properties. Bioresources 2019, 14, 5150-5161.

24. Li, J.; Wang, Q.; Li, S.; Wu, S. Study on flame retardancy of wood flame retardant FRW by CONE method. For. Sci. 2002, 38, 108-114.

25. Song, Z. Controllable Preparation, Drug Delivery and Anti-Tumor Properties of Nano-Hydrotalcite Compounds; Shanghai Normal University: Shanghai, China, 2015.

26. Chang, P.; Chang, Y.; Lai, Y.; Chen, S.; Yu, C.; Chyou, Y. Synthesis, characterization and high temperature CO2 capture capacity of nanoscale Ca-based layered double hydroxides via reverse microemulsion. J. Alloys Compd. 2014, 586, S498-S505. [CrossRef]

27. Du, Y.; Xie, X.; Wu, X.; Hu, X.; Wang, Z. Application of TG-DTA in thermal decomposition of hydrotalcite compounds. Appl. Chem. Ind. 2005, 34, 12-15.

28. Kaul, P.K.; Samson, A.J.; Selvan, G.T.; Enoch, I.V.M.V.; Selvakumar, P.M. Synergistic effect of LDH in the presence of organophosphate on thermal and flammable properties of an epoxy nanocomposite. Appl. Clay Sci. 2017, 135, 234-243. [CrossRef]

29. Du, C.; Yu, H.; Zhou, Z.; Yao, X.; Huang, Q. Flame retardant performance of flame retardant bamboo flooring. For. Prod. Ind. 2017, 44, 7-11.

30. Zhiwei, H.; Mingjie, G. Cone calorimeter analysis of bamboo floor combustion characteristics. J. Southwest Univ. (Nat. Sci. Ed.) 2017, 39, 187-192. 